\title{
Natural Honey Bee Venom for Tissue Expansion in
}

\section{Reconstructive Surgery}

\section{Lasheen $\mathrm{AE}^{*}$, Lasheen MA and Lasheen $\mathrm{OA}$}

Department General and Laparoscopic Surgery, Zagazig University, Egypt

\section{Research Article}

Volume 2 Issue 6

Received Date: November 15, 2018

Published Date: December 20, 2018

DOI: $10.23880 / \mathrm{mjccs}-16000191$

Laparoscopic Surgery, Zagazig University Hospital 44519, Egypt, Tel:

0020552343035; Email: lasheenahmed@yahoo.com

\section{Abstract}

Background: Tissue expansion is one of effective weapon in reconstructive surgery field. But traditional tissue expansion needs much effort and associated by known complications. In this study, tissue expansion is obtained by natural honey bee venom.

Material and Methods: Twenty patients suffering from lesions which needed to excise in different body area, were included in this study. The lesions sizes were varied from $2 \times 3 \mathrm{~cm}$ to $4 \times 7 \mathrm{~cm}$ in different parts of body. Bee sting was used to produce tissue expansion, one sting on both sides of lesion before excision by 24 to 48 hours. Local anesthesia was used to decrease pain sensation before bee sting by 30 minutes.

Results: One bee sting was enough to produce tissue expansion in fine tissue of face. Two bee stings one on both longitudinal sides of lesion were enough to produce tissue expansion in other areas. Bee sting tissue expansion increases the tissue area by about 50\%. All wounds after lesions excision were closed directly without any tension and healed well within 2 to 3 weeks. Conclusion: Tissue expansion by bee sting is easy, simple, safe, effective, and costless in moderate cases.

Keywords: Bee venom; Tissue expansion

\section{Introduction}

The first aim of reconstructive surgery is to restore the tissue loss, especially when is to replace the like with like. Tissue expansion technique provided surgeon to reconstruct the tissue loss by same tissue nature [1-3]. Tissue expansion depends on theory that any living tissue put under tension force for some time will produce hyperplasia and hypertrophy of that tissue [4-7]. These mechanical forces may be internal or external which need more efforts and associated with known complications [8-10]. In this study, we try to find more simple and easy technique for tissue expansion depends on biological effect of bee venom on living tissue.

\section{Material and Methods}

This study included on 20 patients ( 7 females and 13 males). The mean age of patients was 23.5 years (ranging from 12 to 47 years). This patients group consisted of 9 patients with face and neck lesions, 7 patients with upper limb lesions, and 4 patients with trunk lesions. The types of lesions varied from Rodent ulcer, contracted scar, and skin naive. The lesions sizes ranged from $2 \times 3 \mathrm{~cm}$ to $4 \times 7 \mathrm{~cm}$. This study was 


\section{Medical Journal of Clinical Trials \& Case Studies}

approved by Ethical committee of Zagazig University at January 2017 and study started February 2017. Consent was taken from all patients and including their data in this study. The using bees were taken from bee home before using by two hours and kept in clean container until used. Local anesthesia was used before bee sting by 30 minutes to elevate the pain. Every patient is exposed to two bee stings, one sting on both longitudinal sides of lesion before excision by 24 to 48 hours except patient with face lesion exposed to one sting only. The lesion excision was done after 24 to 48 hours of bee sting under local anesthesia in all cases. The wound after lesion excision was reconstructed by direct closure without any flap and very easy by simple sutures. Broad spectrum antibiotic was used by all patients for 5 days postoperative wound leave exposed after 24 hours with ordinary local wound care. Follow up period ranged from 9 to 18 months (mean 12 months).

\section{Results}

The maximum tissue expansion after bee sting was reached after 24 hours in fine areas as face and neck, and after 48 hours in coarse skin of trunk and upper limb. All patients not feel any pain during bee sting. But some patients suffered from itching around the site of bee sting which treated by one dose of antihistaminic drug. All wounds after lesion excision were closed directly without any tension and noted tissue edema during dissection. All wounds healed well within 3 weeks. The appearance and function of healed skin were satisfactory. No complications were occurred at the site of operation during the period of follow up period.

\section{Discussion}

Previous tissue expansion whatever internal or external expansion is mechanical process. This mechanical process leads to hypertrophy and hyperplasia of living tissue $[5,11]$. The complications rate was $30 \%$ with traditional tissue expansion which including failure of process (premature loss of expander that required additional surgery) as infection, implant exposure and failure, port failure, seroma, and bone resorption [9,12]. External tissue expansion needs much effort from patient and surgeon [7]. Tissue expansion by bee sting is a biological process due to the effect of bee venom on living tissue. Bee venom is a natural toxin produced by the honey bee for defense on the bee colony. It contains peptides (melittin, apamin, adolapamin and mast cell degranulating peptide), enzymes (phospholipase, hyaluranidase and lysophosphlipase), and nonpeptides such as histamine, dopamine and norepinephrine [13]. Bee venom was used in treating of rheumatoid arthritis, lateral sclerosis, atherosclerosis, parkinson's disease, liver fibrosis, and Alzheimer's disease [14]. This study is first research to use bee venom for biological tissue expansion.

\section{Conclusion}

We think that bee sting can be expanded the tissue up to $50 \%$ by its biological effect, without any effort and costless. Wound healed well without any complications.

\section{References}

1. Neumann CG (1957) The expansion of an area of skin by progressive distension of a subcutaneous balloon use of the method for securing skin for subtotal reconstruction of the ear. Plast Reconstr Surg 19(2): 124-130.

2. Radovan C (1982) Breast reconstruction after mastectomy using the temporary expander. Plast Reconstr Surg 69(2): 195-208.

3. Austad ED, Rose GL (1982) A self-inflating tissue expander. Plast Reconstr Surg 70(5): 588-594.

4. Wagh MS, Dixit V (2013) Tissue expansion: Concepts, techniques and unfavorable results. Indian J Plast Surg 46(2): 333-348.

5. Bertozzi N, Pesce M, Santi P, Raposio E (2017) Tissue expansion for breast reconstruction: Methods and techniques. Ann Med Surg 21: 34-44.

6. Ratmam BV (2015) A simple external tissue expansion technique based on viscoelastic properties of skin to attain direct closure of a large scalp defect: A case report. Indian J Plast Surg 48(3): 309-312.

7. Lasheen AE, Khaled Saad, Mahmoud Raslan (2009) External tissue expansion in head and neck reconstruction. J Plast Reconst Aesthet Surg 62(8): 251-254. 


\section{Medical Journal of Clinical Trials \& Case Studies}

8. Cunha MS, Nakamoto HA, Herson MR, Faces JC, Gemperli R, et al. (2002) Tissue expander complications in plastic surgery: a 10 year experience. Rev Hosp Clin Fac Med Sao Paulo 57(3): 93-97.

9. Wang J, Huang X, Liu K, Gu B, Li Q (2014) Complications in tissue expansion : an update retrospective analysis of risk factors. Handchir Mikrochir Plast Chir 46(2): 74-79.

10. Smolle C, Tuca A, Wurzer P, Spendel SM, Forbes AA, et al. (2017) Complications in tissue expansion: A logistic regression analysis for risk factors. Burn 43(6): 1195-1202.
11. Argenta LC, Marks MW, Pasyk KA (1985) Advances in tissue expansion. Clin Plast Surg 12(2): 159-171.

12. Friedman RM, Ingram AE, Rohrich RJ, Byrd HS, Hodges PL, et al. (1996) Risk factors for complication in pediatric tissue expansion. Plast Reconstr Surg 98(7): 1242-1246.

13. Lee W, Pak S, Park K (2015) The protective effect of bee venom on fibrosis causing inflammatory diseases. Toxins 7(11): 4758-4772.

14. Zhang S, Liu Y, Ye Y, Wang XR, Lin LT, et al. (2018) Bee venom therapy : potential mechanisms and therapeutic applications. Toxicon 148: 64-73. 